\title{
Barriers imposed in the relationship between puerperal mothers and newborns in the pandemic scenario of COVID-19
}

Monique Maria Silva da Paz 1

https://orcid.org/0000-0002-5366-5984

Milene de Oliveira Almeida 2

iD https://orcid.org/0000-0003-3553-5665

Nadine Oliveira Cabral 3

https://orcid.org/0000-0002-9193-8007

Thais Josy Castro Freire de Assis 4

https://orcid.org/0000-0003-2820-5393
Cristina Katya Torres Teixeira Mendes 5

iD https://orcid.org/0000-0002-5148-8283

1-5 Universidade Federal da Paraíba. Campus I. Cidade Universitária. João Pessoa, PB, Brasil. CEP: 58.051-900. E-mail: moniquemariaspaz@hotmail.com

\begin{abstract}
A new virus called Sars-CoV-2, or COVID-19, emerged in late 2019 and caused several changes worldwide. In light of this, countries adopted preventive measures against this pandemic, such as social isolation, use of personal protective equipment (PPE) and special care with people who are at higher risk, such as elderly, people with hypertension or chronic conditions, and recently newborns, pregnant and puerperal women were also included. For puerperal women breastfeeding, it is an extremely important moment, which, in addition to being a natural feeding moment, it is an opportunity to strengthen the mother-baby bond. Aiming at a more cautious approach to avoid possible transmissions of COVID-19 during breastfeeding, preventive measures can hinder this binomial and bring harm to both.
\end{abstract}

Key words Postpartum period, Breastfeeding, Pandemic, Maternal and child health

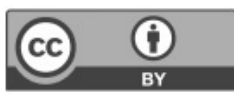




\section{Introduction}

COVID-19 emerged in late 2019 in China and proved to be highly transmissible. To prevent the virus from quickly spreading, extensive testing and social isolation measures were created. However, with globalization and the constant flow of people traveling across borders, such measures were not sufficient to prevent the spread of the virus to other countries. ${ }^{1}$ According to data taken from the Brazilian Ministry of Health's Epidemiological Bulletin of April 17, 2020, Brazil was the 11th country in number of confirmed cases, with a mortality of $6.4 \%$ and a mortality rate of 10 per $1,000,000$ inhabitants. According to projections by the Brazilian Institute of Geography and Statistics (IBGE), the incidence coefficient is 160 per $1,000,000$ inhabitants, varying according to the state and Brazilian region. ${ }^{2}$

In Brazil, risk groups were identified for better control and monitoring during the epidemic, such as elderly, people with hypertension or chronic respiratory problems and, recently included, pregnant and postpartum women. According to the Brazilian Secretariat of Primary Health Care (SAPS Portuguese acronym), postpartum mothers have a higher risk of severity if infected by the virus, 2 thus showing how compliance with the guidelines is a form of prevention of paramount importance. Puerperal women can be affected in many ways during this period, because, in addition to physical, hormonal and emotional changes inherent to this phase, there is also the change in habits in relation to baby care and breastfeeding.

Feeding the newborn is a part of the routine of care, which, as recommended by the World Health Organization (WHO), must be done through breastfeeding from birth up until six months of age.

The act of breastfeeding is triggered by sucking, which activates mechanoreceptors in the breast, followed by sensory signals being sent to the neurohypophysis, which stimulates the secretion of oxytocin and induces the production of prolactin. Prolactin, in turn, binds itself to the membrane receptors of the breast's alveolar cells, which induces production and secretion of milk in the lumen of the alveoli. The oxytocin, on the other hand, binds to its receptors in the myoepithelial cells of the mammary alveolus, inducing its contraction and secretion of breast milk. ${ }^{3}$

However, this is not the only function of oxytocin, popularly known as the 'love hormone', which has its levels increased during breastfeeding. According to Russo and Nucci, 4 it "is seen as responsible not only for the progression of natural birth, but also for the intense affective bond that is established immediately (and naturally) between the mother and the newborn baby." Therefore, both physiologically and emotionally, the act of breastfeeding is crucial for the puerperium; the hormones involved in this process, prolactin and oxytocin, trigger positive effects, being the main one to prevent the occurrence of postpartum depression, since it "attenuates stress responses". ${ }^{5}$ Meanwhile, levels of cortisol, the 'hormone of stress', suffer a substantial drop. "The reduced cortisol responses to stress, as well as the attenuated responses to stress with total cortisol and responses to stress from free cortisol, were shown in lactating mothers compared to non-lactating mothers". 5 In addition, sleep deprivation, difficulties in breastfeeding and atypical circumstances can predispose the appearance of postpartum depression. 6

Bearing this in mind, the aim of this study is to analyze the clinical conditions for breastfeeding, which is a crucial opportunity for mothers and their children, in addition to the pre-existing guidelines on this topic. This study also observed the impacts of the Sars-CoV-2 pandemic on the emotional bond of the mother-fetus binomial.

Correlation between breast milk and Sars-CoV2 and current recommendations about breastfeeding

The current recommendations regarding breastfeeding are the maintenance of breastfeeding, even for mothers who have suspected or confirmed COVID-19 diagnosis, emphasizing the precautions that must be followed such as the mother properly washing her hands before touching the child in addition to the use of mask when breastfeeding. When the use of breast pumps is necessary, it is recommended for the mother to wash her hands before and after handling it. There is no evidence that the virus can be transmitted by breast milk, therefore, these recommendations aim to protect the child exclusively from the mother's respiratory droplets during breastfeeding. ${ }^{7}$

According to Lamounier et al.,8 "although human milk contains antibodies, mononuclear cells and other protective factors, in some maternal illnesses it can function as a possible source of infection for the child.", including viral conditions such as human immunodeficiency virus (HIV), human Tlymphotropic virus (HTLV), hepatitis, herpes virus and measles. To date, there is no evidence that the same happens with Sars-CoV-2, so the recommenda- 
tion to initiate or continue breastfeeding prevails, since there are many benefits.

It is important to emphasize that there is scientific evidence that after the birth of the newborn (NB), the mother transmits defense factors to the baby through breast milk, reducing the risks of infections and being an important factor for the development of the immune system of the NB. ${ }^{9}$ When analyzing breast milk, a case study reported that SARS-CoV antibodies were found. 10

\section{Establishing the bond between} postpartum women and newborn and obstacles imposed by the COVID-19 pandemic

Breastfeeding is essential to create the mother-baby bond, which strengthens through affection and care, in addition to adequate nutrition. 11 The environment in which they find themselves is of great relevance for a better development of the baby and promotes a bond between mother and child, 12 but with the current social context, the mother's feelings of fear and anxiety can have an impact on the development of this bond and on the health of them both. 13

The main and most effective preventive measure worldwide is social isolation, which aims to reduce the emergence of new cases by decreasing interpersonal transmission through coughing, sneezing and touching. Regarding COVID-19, this isolation takes place in the home environment, and can also be carried out in public or private hospitals. 14 Social distancing aims to narrow the virus contamination curve, avoiding the overcrowding of health services and allowing it to be able to reinforce its structure with ventilators, tests for COVID-19 and PPE's, and also preparing the healthcare team for a more qualified approach. 15

Thereafter, some guidelines were made available for the hospital environment, where the NB of a mother with confirmation or suspicion of the disease must stay, after delivery, with the mother, however the cradle and the maternal bed must be separated by a distance of 3 feet ( 1 meter). If the NB is premature and needs to be admitted to the Intensive Care Unit (ICU), contact precautions should be maintained and testing for the new virus must be done within the first 48 hours. If the result is negative, the NB contact precautions can be removed. 16

During this period of social isolation, where home confinement is recommended, individuals tend to adopt lifestyle habits that are different than usual, which may result in psychosocial disorders, such as anxiety and depression. ${ }^{17}$ A study conducted in China classified the psychological impact of the epidemic as moderate to severe in approximately half of the interviewees. When analyzing the intensity of anxiety, about a third of the individuals reported having the disorder in a moderate to severe way. 18

Therefore, in this context of quarantine, the mother who may have or who has been diagnosed suffers because she needs to avoid direct contact with her child, and as a result, they are prone to develop anxiety, stress and postpartum depression. It is known that the social context of quarantine and all the unanswered questions about COVID-19 predisposes the accentuation of such psychic conditions in these women. ${ }^{19}$ Furthermore, breastfeeding is a remarkable moment, because in addition to being a complete form of nutrition for the child, it allows the formation of a mother and child bond, which can be affected by the preventive measures against the new virus.

\section{Final considerations}

Therefore, even within this atypical context of COVID-19 pandemic and social isolation, the interaction, breastfeeding and bonding between mother and child must continue to be built, even if limited by physical barriers represented by the protective measures, which are essentially necessary in this period, such as the use of masks and constant cleaning of the skin of both mother and child, as recommended by health organizations.

\section{Authors' contribution}

Paz MMS, Almeida MO and Cabral NO collaborated with the writing of the manuscript. Assis TJCF and Mendes CKTT collaborated with the proofreading of the article. All authors approved the final version of the manuscript and are publicly responsible for the content of the publication. 


\section{References}

1. Farias HS. O avanço da Covid-19 e o isolamento social como estratégia para redução da vulnerabilidade. Espaço Econ. 2020; 17. Disponível em: https://journals.openedition.org/espacoeconomia/11357\#text

2. Brasil. Ministério da Saúde. Secretaria de Vigilância em Saúde. Boletim Epidemiológico 11. Doença pelo Coronavírus 2019 (COE - COVID-19). 2020. Disponível em:

https://portalarquivos.saude.gov.br/images/pdf/2020/April/ 18/2020-04-17---BE11---Boletim-do-COE-21h.pdf

3. Aires MM. Fisiologia. 5 ed. Rio de Janeiro: Guanabara Koogan; 2018

4. Russo JA, Nucci MF. Giving birth in paradise: humanized birth, oxytocin, and the bodily production of a new maternity. Interface. 2020; 24: e180390.

5. Figueiredo B, Dias CC, Brandão S, Canário C, Nunes-Costa R. Breastfeeding and postpartum depression: state of the art review. J Pediatr (Rio J). 2013; 89 (4):332-8.

6. Lopes MWP, Gonçalves MJR. Avaliar os motivos da depressão pós-parto: uma revisão bibliográfica de literatura. Rev JRG Estud Acad. 2020. 3:(6) 82-95.

7. CDC (Centers for Disease Control and Prevention). Interim Considerations for Infection Prevention and Control of Coronavirus Disease 2019 (COVID-19) in Inpatient Obstetric Healthcare Settings. 2020 February 25. Disponível em: https://www.cdc.gov/coronavirus/2019ncov/hcp/inpatient-obstetric-healthcare-guidance.html

8. Lamounier JA, Moulin ZS, Xavier CC. Recomendações quanto à amamentação na vigência de infecção materna. J Pediatr (Rio J). 2004; 80: 181-8.

9. Primo CC, Amorim MHC, Leite FMC. La intervención de enfermería relajación y sus efectos em el sistema inmunológico de puérperas. Acta Paul Enferm. 2011, 24(6): 751-5.

10. Robertson CA, Lowther SA, Birch T, Tan C, Sorhage F, Stockman L, McDonald LC, Lingappa JR, Bresnitz E. SARS and pregnancy: a case report. Emerg Infect Dis. 2004; 10 (2): 345-8.

11. Mendes SC, Lobo IKV, Sousa SQ, Vianna RPT. Fatores relacionados com uma menor duração total do aleitamento materno. Ciênc Saúde Coletiva. 2019. 24: 1821-1829.
12. Azevedo EC, Frizzo GB, Silva MR, Donelli TMS. Leitura materna sobre depressão pós-parto e sintomas psicofuncionais: um caso de psicoterapia mãe-bebê. Psicol Clin. 2020; 32 (1): 79-100.

13. Bezerra AEM, Batista LHC, Santos RGA. Amamentação: o que pensam as mulheres participantes de um grupo de prénatal? Rev Bras Enferm. 2020; 73 (3): e20180338.

14. Melo K. COVID-19: saiba a diferença entre quarentena e isolamento. [acesso 17 Abril 2020]. Disponível em: https://agenciabrasil.ebc.com.br/saude/noticia/202003/covid-19-saiba-diferenca-entre-quarentena-e-isolamento

15. Brasil. Ministério da Saúde. Protocolo de Manejo Clínico do Coronavírus (COVID-19) na Atenção Primária à saúde; 2020. Disponível em: https://saude.gov.br/images/pdf/ 2020/marco/30/20200330-ProtocoloManejo-ver06Final.pdf

16. Santos CAD, Alves MM, Barreto CTR, Macedo EYL, Freitas Júnior RAO. Novo Coronavírus e gravidez: manejo dos casos de gestantes com suspeita de COVID-19. Instituto Santos Dumont; 2020. Disponível em: http://www.institutosantosdumont.org.br/wp-content/ uploads/2020/04/Fluxograma-para-atendimento-degestantes-com-COVID.pdf

17. Ferreira MJ, Irigoyen MC, Consolim-Colombo F, Saraiva JFK, Angelis K. Vida Fisicamente Ativa como Medida de Enfrentamento ao COVID-19. [Editorial] Arq Bras Cardiol. AHEAD, 2020; 114 (4): 601-2.

18. Wang C, Pan R, Wan X, Tan Y, Xu L, Ho CS, Ho RC. Immediate psychological responses and associated factors during the initial stage of the 2019 coronavirus disease (COVID-19) epidemic among the general population in China. Int J Environ Res Public Health. 2020; 17 (5): 1729.

19. Jardim T, Viana GP, Cruz WO, Assis TO, Lemos GD, Almeida KJS, Maia CS, Lemos-Jordão AJJM. Principais fatores relacionados à impossibilidade de amamentação em Puérperas assistidas no Isea. Braz J Health Rev. 2019; 2 (6): 5024-46.

Received on June 12, 2020

Approved on July 13, 2020 